\title{
Cellular prion protein promotes post-ischemic neuronal survival, angioneurogenesis and enhances neural progenitor cell homing via proteasome inhibition
}

\author{
TR Doeppner, ${ }^{*, 1,2,6}$, B Kaltwasser ${ }^{1}$, J Schlechter ${ }^{1}$, J Jaschke ${ }^{3}$, E Kilic ${ }^{2}$, M Bähr ${ }^{4}$, DM Hermann ${ }^{1}$ and J Weise ${ }^{3,5}$
}

\begin{abstract}
Although cellular prion protein $\left(\mathrm{PrP}^{\mathrm{c}}\right)$ has been suggested to have physiological roles in neurogenesis and angiogenesis, the pathophysiological relevance of both processes remain unknown. To elucidate the role of $\operatorname{PrP}^{\mathrm{C}}$ in post-ischemic brain remodeling, we herein exposed $\operatorname{PrP}^{\mathrm{c}}$ wild type (WT), $\operatorname{PrP}^{\mathrm{c}}$ knockout $(\operatorname{PrP}-/-)$ and $\mathrm{PrP}^{\mathrm{c}}$ overexpressing $(\mathrm{PrP}+/+)$ mice to focal cerebral ischemia followed by up to 28 days reperfusion. Improved neurological recovery and sustained neuroprotection lasting over the observation period of 4 weeks were observed in ischemic PrP $+/+$ mice compared with WT mice. This observation was associated with increased neurogenesis and angiogenesis, whereas increased neurological deficits and brain injury were noted in ischemic PrP $-I-$ mice. Proteasome activity and oxidative stress were increased in ischemic brain tissue of PrP $-I-$ mice. Pharmacological proteasome inhibition reversed the exacerbation of brain injury induced by $\operatorname{PrP}-I-$, indicating that proteasome inhibition mediates the neuroprotective effects of $\mathrm{PrP}^{\mathrm{c}}$. Notably, reduced proteasome activity and oxidative stress in ischemic brain tissue of $\mathrm{PrP}+/+$ mice were associated with an increased abundance of hypoxia-inducible factor $1 \alpha$ and PACAP-38, which are known stimulants of neural progenitor cell (NPC) migration and trafficking. To elucidate effects of PrPc on intracerebral NPC homing, we intravenously infused GFP+ NPCs in ischemic WT, PrP $-I-$ and PrP $+/+$ mice, showing that brain accumulation of $\mathrm{GFP}^{+}$NPCs was greatly reduced in PrP $-I$ - mice, but increased in $\mathrm{PrP}+/+$ animals. Our results suggest that $\mathrm{PrP}^{\mathrm{c}}$ induces postischemic long-term neuroprotection, neurogenesis and angiogenesis in the ischemic brain by inhibiting proteasome activity.

Cell Death and Disease (2015) 6, e2024; doi:10.1038/cddis.2015.365; published online 17 December 2015
\end{abstract}

Endogenous neurogenesis persists in the adult rodent brain within distinct niches such as the subventricular zone (SVZ) of the lateral ventricles, ${ }^{1-4}$ which host astrocyte-like neural stem cells and neural progenitor cells (NPCs). Focal cerebral ischemia stimulates neurogenesis, and NPCs proliferate and migrate towards the site of lesion where they eventually differentiate. ${ }^{5-7}$ In light of low differentiation rates and high cell death rates of newborn cells, ${ }^{6,8,9}$ post-stroke neurogenesis is scarce. ${ }^{10}$

Cellular prion protein $\left(\mathrm{PrP}^{\mathrm{C}}\right)$ is a glycoprotein that is attached to cell membranes by means of a glycosylphosphatidylinositol anchor. ${ }^{11}$ Although $\mathrm{PrP}^{\mathrm{c}}$ is ubiquitously expressed, it is most abundant within the central nervous system. Conversion into its misfolded isoform $\mathrm{PrP}^{\mathrm{sc}}$ causes neurodegenerative diseases such as Creutzfeldt-Jacob disease. ${ }^{11,12}$ While a large body of studies analyzed the role of $\mathrm{PrP}^{\mathrm{sc}}$ in the context of transmissible spongiform encephalopathies, little is known about the physiological role of $\mathrm{PrP}^{\mathrm{c}}$. Studies performed during both ontogenesis and adulthood suggest that $\mathrm{PrP}^{\mathrm{C}}$ regulates neuronal proliferation and differentiation, synaptic plasticity and angiogenesis. ${ }^{13-18}$ The role of these processes under pathophysiological conditions, however, is largely unknown.

Previous reports suggested a role of $\mathrm{PrP}^{\mathrm{c}}$ in post-ischemic neuroprotection. ${ }^{19-24}$ Thus, $\operatorname{PrP}^{c}$ was found to be overexpressed in ischemic brain tissue. ${ }^{19-24} \mathrm{PrP}^{\mathrm{C}}$ deficiency aggravated ischemic brain injury, possibly via enhanced ERK-1/2 activation and reduced phosphorylation of Akt, thus ultimately culminating in increased caspase-3 activity, ${ }^{21,24}$ whereas $\mathrm{PrP}^{\mathrm{C}}$ overexpression protected against ischemia. ${ }^{19-24}$ Nevertheless, these studies focused on acute injury processes with a maximal observation period of 3 days, leaving the biological role of $\mathrm{PrP}^{\mathrm{C}}$ in post-stroke neurogenesis and angiogenesis unanswered. To clarify the role of $\mathrm{PrP}^{\mathrm{c}}$ in the post-acute ischemic brain, we herein exposed $\mathrm{PrP}^{\mathrm{c}}$ wild type (WT), $\mathrm{PrP}^{\mathrm{c}}$ knockout (PrP $-/-)$ and $\operatorname{PrP}^{\mathrm{C}}$ overexpressing $(\mathrm{PrP}+/+)$ mice to focal cerebral ischemia induced by intraluminal middle cerebral artery (MCA) occlusion, evaluating effects of $\mathrm{PrP}^{\mathrm{c}}$ on neurological recovery, ischemic injury, neurogenesis and angiogenesis, as well as the homing and efficacy of exogenously delivered NPCs.

\footnotetext{
${ }^{1}$ Department of Neurology, University of Duisburg-Essen Medical School, Essen, Germany; ${ }^{2}$ Regenerative and Restorative Medical Research Center, Istanbul Medipol University, Istanbul, Turkey; ${ }^{3}$ Department of Neurology, University of Jena, Jena, Germany; ${ }^{4}$ Department of Neurology, University of Goettingen, Goettingen, Germany and ${ }^{5} \mathrm{HELIOS}$ Clinic Plauen, Department of Neurology, Plauen, Germany

*Corresponding author: TR Doeppner, Department of Neurology, University Hospital Essen, Hufelandstr. 55, Essen 45147, Germany. Tel: +49 20172383586 ; Fax: +49 201 723 1660; E-mail: thorsten.doeppner@uk-essen.de

${ }^{6}$ Present address: Department of Neurology, University of Goettingen, Goettingen, Germany.

Abbreviations: AMC, 7-amino-4-methylcoumarin; ARRIVE, Animal Research: Reporting of In Vivo Experiments; Brdu, bromodeoxyuridine; CCA, common carotid artery; Dcx, doublecortin; DMSO, dimethyl sulfoxide; ERK, extracellular signal-regulated kinases; GFP, green fluorescence protein; HIF-1 $\alpha$, hypoxia-inducible factor $1 \alpha$; MCA, middle cerebral artery; NPCs, neural progenitor cells; PACAP-38, pituitary adenylate cyclase-activating peptide-38; $\operatorname{PrP}^{\mathrm{c}}$, cellular prion protein; $\mathrm{PrP}-1$ - , PrP $\mathrm{K}^{\mathrm{k}}$ knockout; PrP+/+, PrP ${ }^{C}$ overexpressing; STI-1, stress-inducible protein-1; Suc-LLVY-AMC, SuccSinyl-Leu-Leu-Val-Tyr-AMC; SVZ, subventricular zone; TBARS, thiobarbituric acid reactive substances; TTC, 2,3,5-triphenyltetrazolium chloride; WT, wild type

Received 25.5.15; revised 30.10.15; accepted 16.11.15; Edited by A Yaron
} 
a

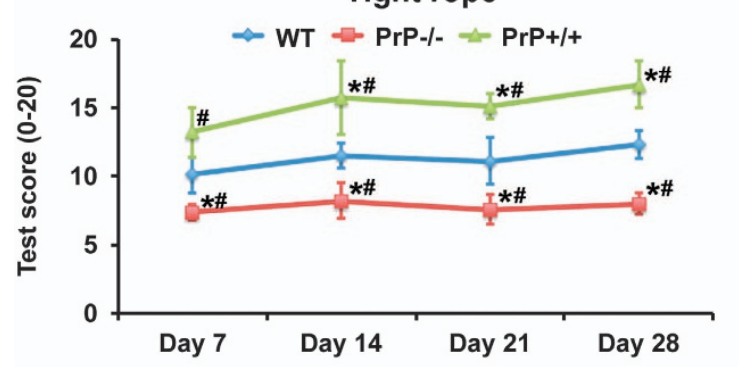

c

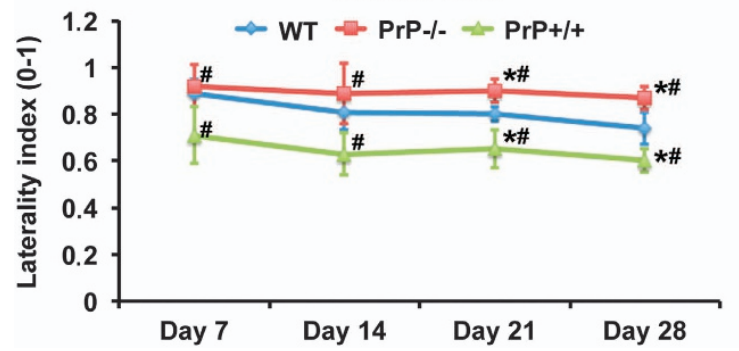

b

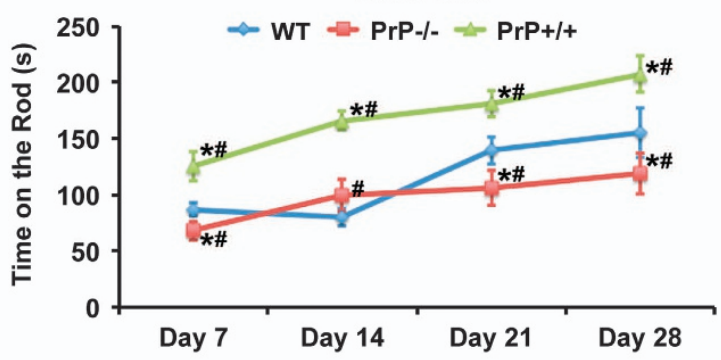

d

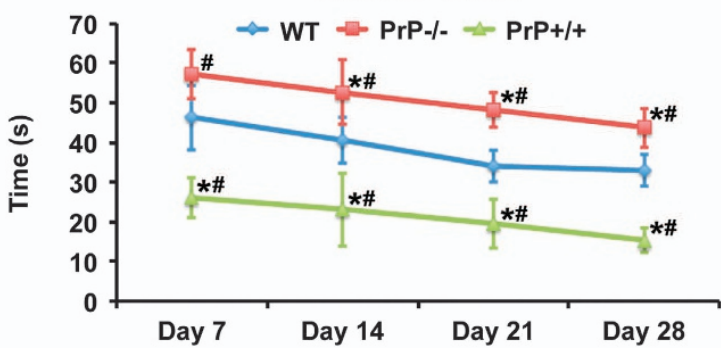

Figure 1 Cellular prion protein $\left(\mathrm{PrP}^{\mathrm{C}}\right)$ ameliorates post-ischemic neurological impairment. (a) Tight rope, (b) rota rod, (c) corner turn and (d) balance beam test in wild type (WT), PrPc knockout (PrP $-/-$ ) and PrPC overexpressing (PrP+/+) mice exposed to 45 min of MCA occlusion followed by 28 days reperfusion. ${ }^{*}$ Significantly different from WT mice, $P<0.05$. "Significantly different from $\mathrm{PrP}-1-$ or $\mathrm{PrP}+/+$ mice, $P<0.05$

\section{Results}

$\operatorname{PrP}^{c}$ ameliorates post-stroke neurological impairment and induces long-term neuroprotection. Before analyzing effects of $\mathrm{PrP}^{\mathrm{c}}$ on both neurogenesis and underlying mechanisms, we first assessed whether or not $\mathrm{PrP}^{\mathrm{c}}$ induces sustained reduction of motor coordination impairment and histological brain injury. Using the tight rope, rota rod, corner turn and balance beam test, assessment of motor coordination for as long as 28 days after 45 min MCA occlusion revealed significantly improved neurological recovery in $\mathrm{PrP}$ +/+ mice when compared with both WT mice and PrP - / mice (Figure 1). On the contrary, PrP $-/-$ mice showed significantly reduced neurological recovery not only when compared with $\mathrm{PrP}+/+$ mice but also in comparison with WT mice (Figure 1). In line with better test performance of $\mathrm{PrP}+/+$ mice, $\mathrm{PrP}+/+$ mice showed significantly reduced postischemic brain injury when compared with WT mice and PrP - / - mice (Figure 2). Again, PrP - / - mice did not only show increased brain injury when compared with $\mathrm{PrP}+/+$ mice, but also developed significantly larger brain injury in comparison with WT animals (Figure 2). Of note, less than one percent of the total amount of $\mathrm{NeuN}^{+}$cells shown for the analysis of late brain injury (Figure $2 \mathrm{~b}$ ) co-label with BrdU (e.g., $0.53 \%$ cells in the PrP $-/-$ group), thus indicating that the total amount of $\mathrm{NeuN}^{+}$cells depicted in Figure $2 \mathrm{~b}$ depends on neuronal density rather than on neurogenesis.

Post-ischemic neurogenesis and angiogenesis are increased by $\mathrm{PrP}-I-$ and $\mathrm{PrP}+/+$. We next analyzed post-ischemic neurogenesis and angiogenesis on day 28 post-stroke. Analysis of $\mathrm{BrdU}^{+}$cells within the ischemic lesion revealed significantly more $\mathrm{BrdU}^{+}$cells in $\mathrm{PrP}-/$ - than in
WT mice (Figure 3a). Interestingly, $\mathrm{PrP}+/+$ mice exhibited even more $\mathrm{BrdU}^{+}$cells; their number significantly exceeded that in WT mice and PrP - / - mice (Figure 3a). Analysis of differentiation patterns of $\mathrm{BrdU}^{+}$cells revealed significantly increased co-expression with Dcx, NeuN and CD31 both in $\mathrm{PrP}-/-$ and in $\mathrm{PrP}+/+$ mice (Figures $3 b$ and $d$ ). Again, $\mathrm{PrP}+/+$ mice showed significantly higher figures than $\mathrm{PrP}-/-$ mice (Figures $3 b$ and $d$ ). These data suggest that both postischemic neurogenesis and angiogenesis are increased in $\mathrm{PrP}-/$ - mice and in PrP+/+ animals.

Enhanced post-ischemic neurogenesis and angiogenesis in $\operatorname{PrP}-/-$ mice is a consequence of increased brain injury. Neurogenesis and angiogenesis are stimulated upon focal cerebral ischemia in a way that closely depends on the severity of brain injury. ${ }^{5,25}$ To first evaluate whether enhanced neurogenesis and angiogenesis were a consequence of exacerbated brain damage only, we exposed PrP-/ - mice to a shorter MCA occlusion of $30 \mathrm{~min}$, whereas WT mice again were submitted to $45 \mathrm{~min}$ of MCA occlusion. Analysis of infarct volume at $24 \mathrm{~h}$ post-stroke and of neuronal density at 28 day post-stroke revealed a similar extent of brain injury in both groups (Figures $4 a$ and b). Analysis of post-ischemic neurogenesis and angiogenesis on day 28 revealed no significant difference in cell proliferation and cell differentiation (Figures $4 \mathrm{c}$ and $\mathrm{f}$ ). The number of $\mathrm{BrdU}^{+}, \mathrm{Dcx}^{+} / \mathrm{BrdU}^{+}, \mathrm{NeuN}^{+} / \mathrm{BrdU}^{+}$and $\mathrm{CD} 31^{+} / \mathrm{BrdU}^{+}$cells was very similar in both groups.

The aforementioned observations were further backed up by inducing a 75-min stroke in WT mice, which was associated with a similar (enhanced) extent of brain injury compared with a 45-min stroke in $\mathrm{PrP}-1-$ mice. We observed an infarct volume of $62.4 \pm 8.1 \mathrm{~mm}^{3}$ after $24 \mathrm{~h}$ and a neuronal density of 

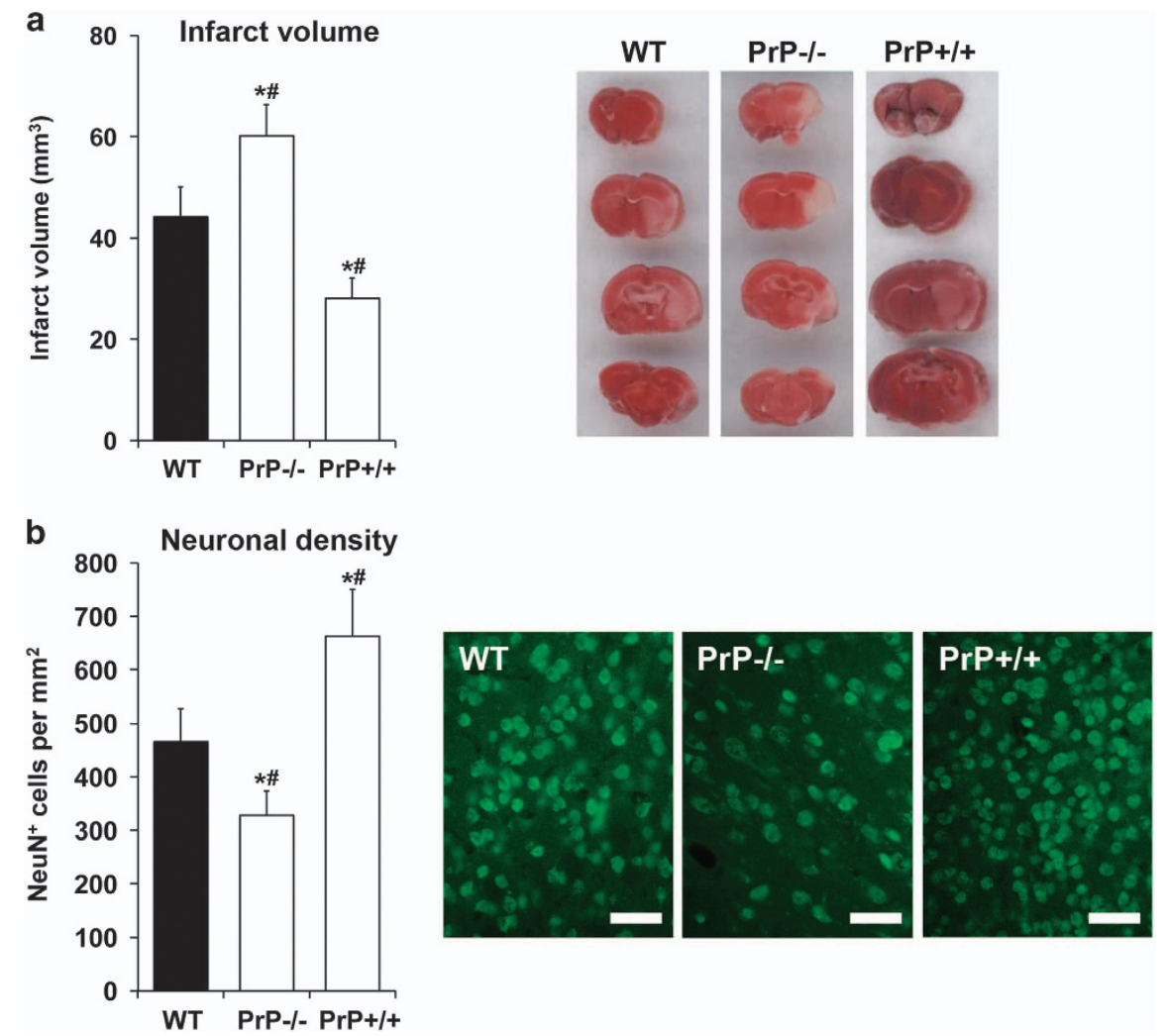

Figure $2 \mathrm{PrP}^{\mathrm{c}}$ induces sustained neuroprotection after focal cerebral ischemia. (a) Infarct volume determined by 2,3,5-triphenyltetrazolium chloride (TTC) staining and (b) neuronal density determined by NeuN immunohistochemistry in the striatum in WT, PrP - / - and PrP+/+ mice exposed to 45 min MCA occlusion followed by $24 \mathrm{~h}$ (in a) or 28 days (in b) reperfusion. Representative photographs are also shown, which in (b) were taken in the core of the ischemic striatum. Scale bars: $20 \mu \mathrm{m}$. ${ }^{*}$ Significantly different from WT mice, $P<0.05$. "Significantly different from PrP $-/$ - or PrP+/+ mice, $P<0.05$

$297.1 \pm 28.5 \mathrm{NeuN}^{+}$cells per $\mathrm{mm}^{2}$ on day 28 in these WT mice. The latter also developed increased amounts of $\mathrm{BrdU}^{+}$ cells $\left(121.7 \pm 9.4\right.$ per $\left.\mathrm{mm}^{2}\right)$ and increased proportions of $\mathrm{Dcx}^{+} /$ $\mathrm{BrdU}^{+}(12.4 \pm 2.0 \%)$ and $\mathrm{NeuN}^{+} / \mathrm{BrdU}^{+}(1.7 \pm 0.39 \%)$ cells, which were on the same order as in $\mathrm{PrP}-/$ - mice exposed to a 45-min stroke. These data suggest that the increased neurogenesis and angiogenesis in $\mathrm{PrP}-/-$ mice is a consequence of increased brain injury.

$\operatorname{PrP}^{c}$ induces post-ischemic neuroprotection via inhibition of proteasome-induced hypoxia-inducible factor $1 a$ degradation. We have previously shown that overexpression of $\mathrm{PrP}^{\mathrm{C}}$ results reduces phosphorylation of ERK-1/2 after focal cerebral ischemia in mice. ${ }^{23}$ ERK-1/2 is activated by the proteasome, ${ }^{26-28}$ which aggravates post-ischemic brain injury via increased oxidative stress and hypoxia-inducible factor $1 a(\mathrm{HIF}-1 a)$ degradation. ${ }^{29}$ To elucidate the role of proteasome activation in $\mathrm{PrP}^{\mathrm{C}}$-induced neuroprotection, we measured proteasomal activity $24 \mathrm{~h}$ after $45 \mathrm{~min}$ of MCA occlusion. Proteasome activity was significantly increased in PrP - / - mice compared with WT mice, and significantly reduced in $\mathrm{PrP}+/+$ mice compared with $\mathrm{WT}$ and, even more so, $\operatorname{PrP}-/-$ mice (Figure 5a). Alterations in proteasome activity were associated with changes in oxidative stress, which was significantly increased in $\mathrm{PrP}-/$ - mice compared with WT mice and significantly reduced in $\mathrm{PrP}+/+$ mice compared with WT and PrP - / - mice (Figure 5b).

Considering that HIF-1 $a$ is degraded by the proteasome and inhibition of proteasomal activity reduces ischemic brain injury, ${ }^{29}$ we next evaluated HIF-1a abundance in western blots, which was significantly reduced by $\mathrm{PrP}-/-$ and significantly increased by $\mathrm{PrP}+/+$ at $24 \mathrm{~h}$ post-stroke (Figure 5c). Further taking into consideration that HIF-1a upregulates the pituitary adenylate cyclase-activating peptide38 (PACAP-38), which activates PACAP type 1 receptor (PAC-1), thereby controlling NPC migration and trafficking, ${ }^{30-32}$ we furthermore determined PACAP-38 abundance in western blots, which was again significantly reduced by $\operatorname{PrP}-/$ - and significantly increased by PrP+/+ (Figure 5c).

To verify whether or not $\mathrm{PrP}^{\mathrm{C}}$-induced post-ischemic neuroprotection involves modification of proteasomal activity, animals received ipsilateral intrastriatal injection of the neuroprotective proteasome inhibitor BSc2118 at $12 \mathrm{~h}$ before stroke. ${ }^{29}$ Application of BSc2118 significantly reduced infarct volume at $24 \mathrm{~h}$ post-stroke in $\mathrm{WT}$ and $\mathrm{PrP}-/$ - mice, with no further benefit in $\mathrm{PrP}+/+$ mice (Figure $5 \mathrm{~d}$ ). Interestingly, in PrP-/- mice receiving BSc2118, infarct volume was reduced to levels similar to WT mice. Likewise, analysis of neuronal density on day 28 revealed that BSc2118-induced neuroprotection in both WT $(692.4 \pm 37.0$ versus $412.7 \pm 24.5$ $\mathrm{NeuN}^{+}$cells per $\mathrm{mm}^{2}$ in controls) and PrP - / - (718.1 \pm 29.7 

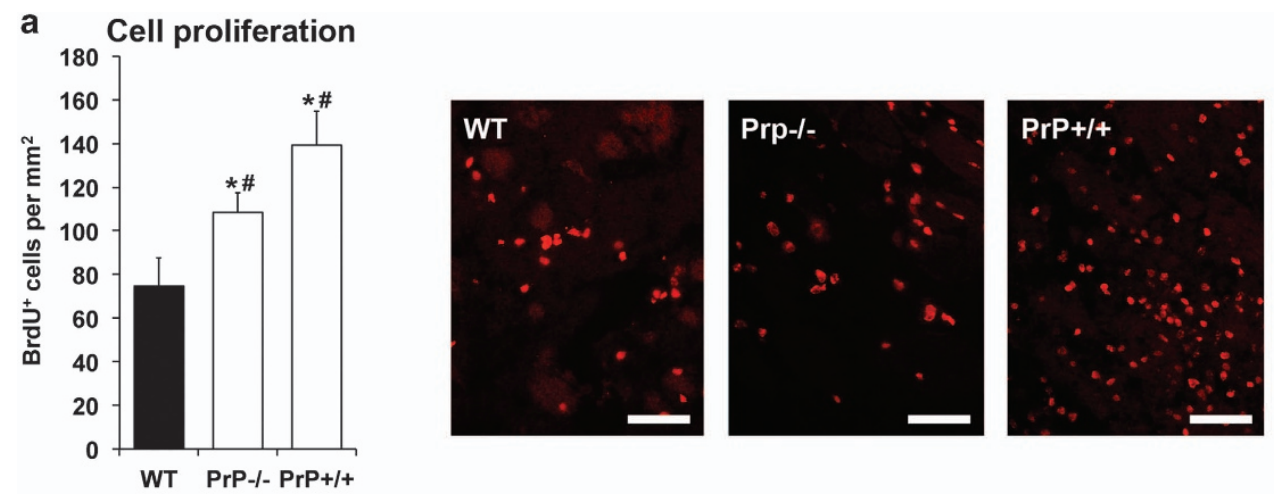

b Neurogenesis (Dcx)
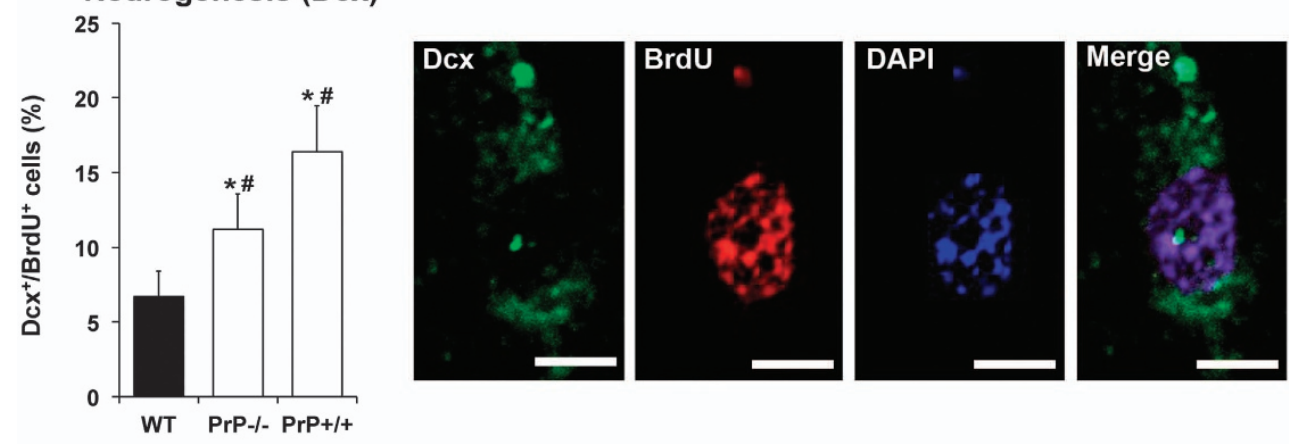

\section{Neurogenesis (NeuN)}
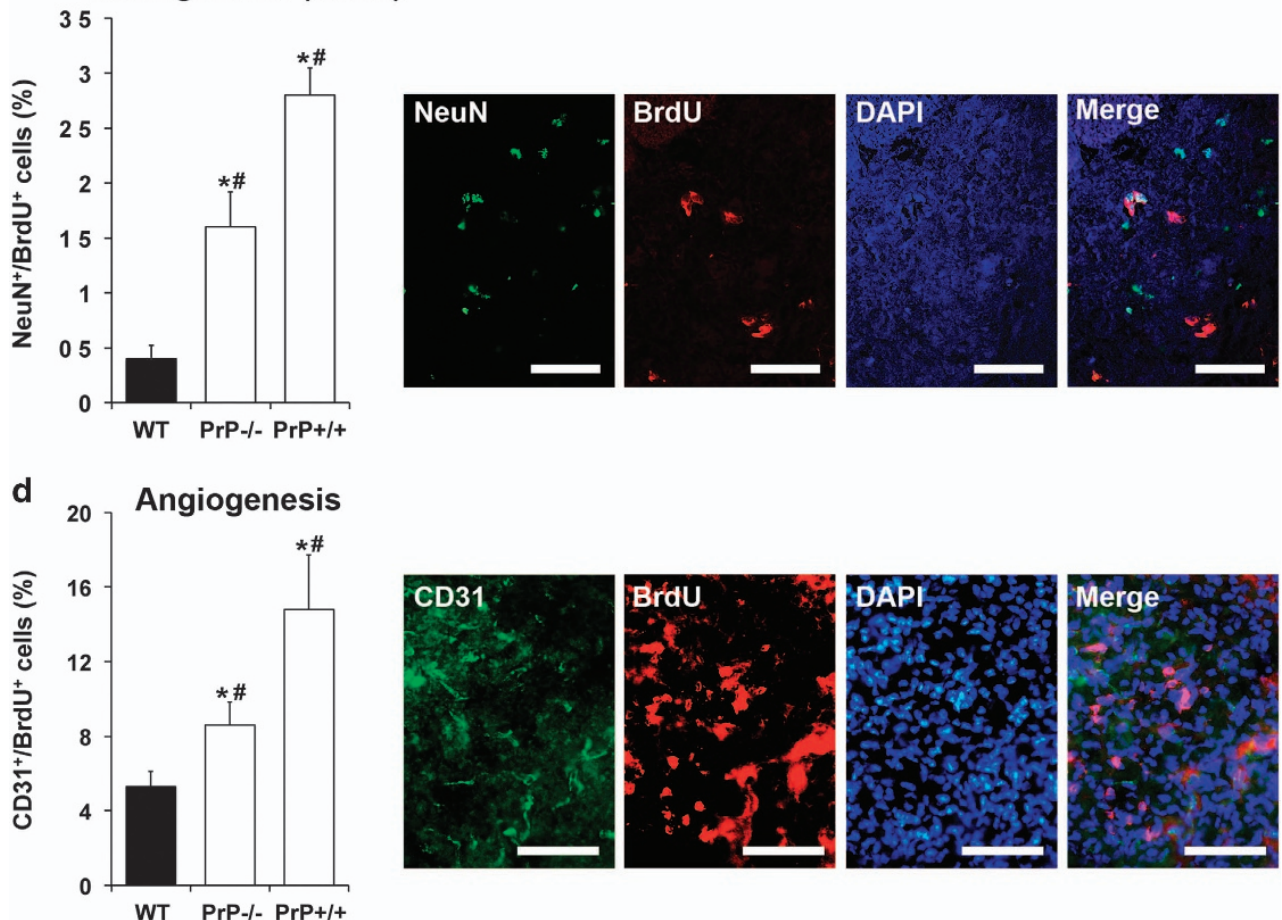

Figure 3 Post-ischemic neurogenesis and angiogenesis are increased in PrP $-/$ - and PrP+/+ mice. (a) Cell proliferation assessed by bromodeoxyuridine (BrdU) immunolabeling, (b) neurogenesis evaluated by co-labeling of the immature neuronal marker $\mathrm{Dcx}$ and $\mathrm{BrdU}$, (c) neurogenesis determined by co-labeling of the mature neuronal marker NeuN and BrdU and (d) angiogenesis examined by co-labeling of the endothelial marker CD31 and BrdU in the striatum of WT, PrP - / - and PrP+/+ mice exposed to $45 \mathrm{~min}$ MCA occlusion followed by 28 days reperfusion. Representative photographs are presented from the core of the ischemic striatum from PrP+/+ mice. Scale bars: $50 \mu \mathrm{m}$. *Significantly different from WT mice, $P<0.05$. "Significantly different from PrP $-/$ - or PrP $+/+$ mice, $P<0.05$ 

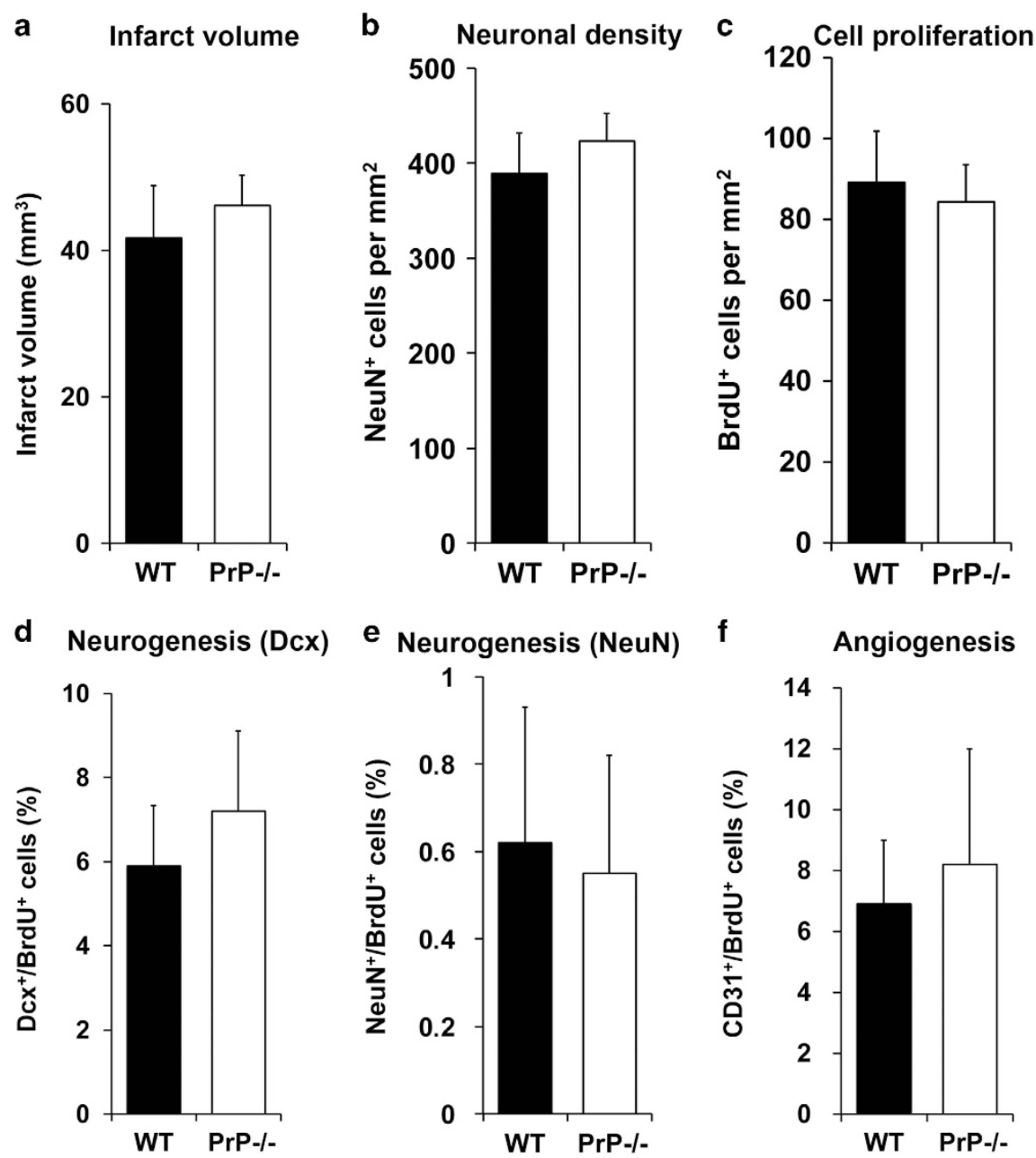

Figure 4 Enhanced post-ischemic neurogenesis and angiogenesis in PrP - / - mice is a consequence of increased infarct size. (a) Infarct volume determined by TTC staining, (b) neuronal density in the striatum determined by NeuN immunohistochemistry, (c) cell proliferation measured by BrdU immunolabeling, (d) neurogenesis evaluated by co-labeling of the immature neuronal marker Dcx and BrdU, (e) neurogenesis assessed by co-labeling of the mature neuronal marker NeuN and BrdU, and (f) angiogenesis examined by co-labeling of the endothelial marker CD31 and BrdU in WT mice exposed to 45 min MCA occlusion and PrP - / - mice exposed to 30 min MCA occlusion followed by $24 \mathrm{~h}$ reperfusion (a) or 28 days reperfusion (b-f). Note that in the presence of very similar brain injury (a and $\mathbf{b})$, post-ischemic cell proliferation (c), neurogenesis (d-e) and angiogenesis (f) do not differ between WT and PrP - / - mice

versus $286.9 \pm 15.8 \mathrm{NeuN}^{+}$cells per $\mathrm{mm}^{2}$ in controls) mice was stable during the observation period. The extent of brain injury in $\mathrm{PrP}+/+$ mice, however, was again not affected by BSc2118 at this late time point $(751.1 \pm 61.2$ versus $704.0 \pm 32.9 \mathrm{NeuN}^{+}$cells per $\mathrm{mm}^{2}$ in controls), as has been observed for the acute time point. Of note, pretreatment with BSc2118 also resulted in increased protein expression of HIF-1 $a$ and PACAP-38 $24 \mathrm{~h}$ post-stroke in both WT and PrP - / - mice (data not shown). These data indicate that the proteasome is critically involved in the aggravation of brain injury in $\mathrm{PrP}-/-$ mice.

PrP $^{c}$ facilitates peri-infarct homing of grafted NPCs. Intravenous transplantation of adult NPCs reduces ischemic brain injury and enhances motor coordination recovery. ${ }^{33,34}$ In light of $\mathrm{PrP}-1-$ mice exhibiting reduced PACAP-38 expression, which is critically involved in NPC migration and trafficking, we finally evaluated the effect of $\mathrm{PrP}^{\mathrm{c}}$ expression on the intracerebral homing of systemically transplanted $\mathrm{GFP}^{+}$NPCs, furthermore examining effects of NPC delivery on ischemic brain injury and neurological recovery. GFP ${ }^{+}$ NPCs were intravenously transplanted in WT, PrP $-/$ - and $\mathrm{PrP}+/+$ mice $6 \mathrm{~h}$ after 45 min MCA occlusion. Compared with WT mice, the homing of $\mathrm{GFP}^{+} \mathrm{NPC}$ in peri-infarct tissue was significantly reduced in $\mathrm{PrP}-/-$ mice and significantly increased in $\mathrm{PrP}+/+$ mice 28 days after stroke (Figure 6a). Pretreatment with $\mathrm{BSc} 2118$ significantly increased the number of GFP $^{+}$NPCs 28 days post-stroke in both WT $\left(58.4 \pm 5.7\right.$ cells per $\left.\mathrm{mm}^{2}\right)$ and PrP $-/-(60.2 \pm 11.3$ cells per $\mathrm{mm}^{2}$ ) mice to levels of $\mathrm{PrP}+/+$ mice (Figure 6a), where the proteasome inhibitor had again no additional effect (data not shown). Notably, the reduced brain accumulation of $\mathrm{GFP}^{+}$ NPCs was associated with a lack of neuroprotection (Figure 6b) and functional neurological recovery (Figures 6c and d) induced by NPC transplantation. Likewise, NPC transplantation did not achieve any therapeutic benefit in 
a

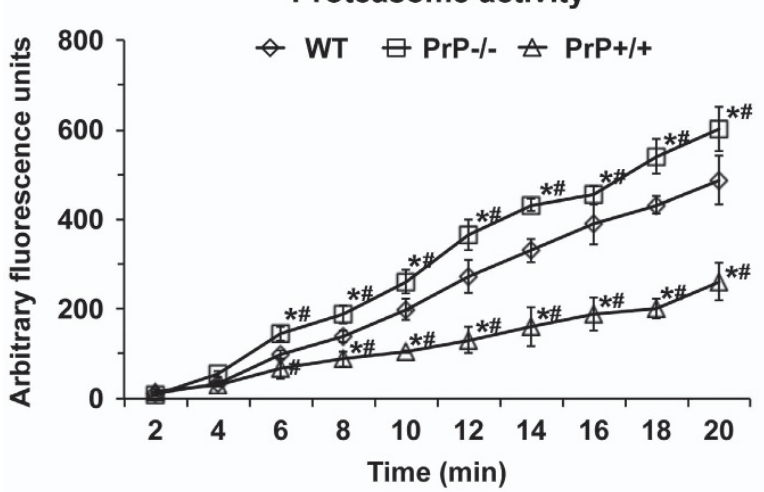

b

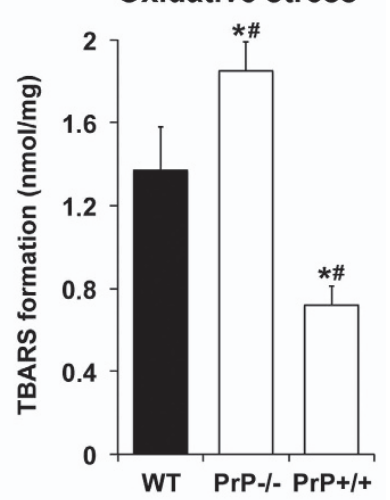

C

Western blotting

WT PrP-I- PrP+l+
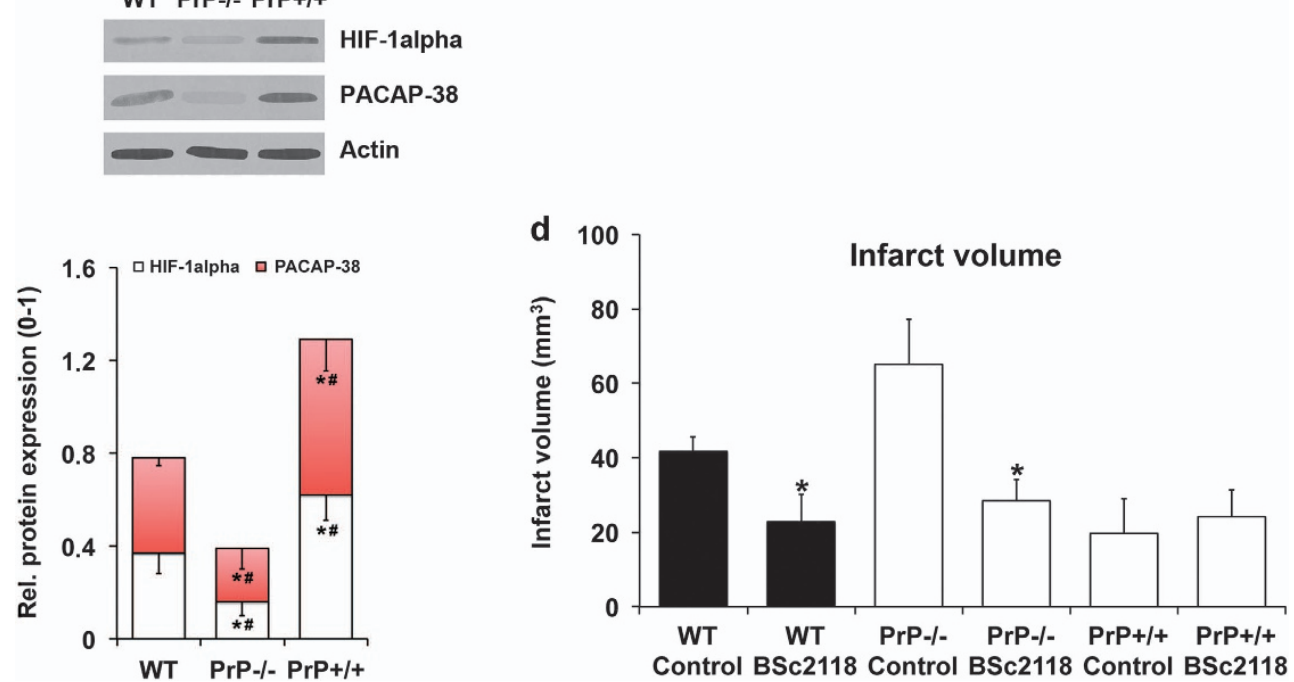

Figure 5 Proteasome-mediated HIF-1 $\alpha$ stabilization initiates PrPc-induced neuroprotection. (a) Proteasomal activity analyzed by Suc-LLVY-AMC cleavage, (b) oxidative stress determined by thiobarbituric acid reactive substances (TBARS) analysis, (c) HIF-1 $\alpha$ and PACAP-38 abundance evaluated by western blotting and (d) infarct volume assessed by TTC staining of WT, PrP - / - and PrP+/+ mice exposed to 45 min MCA occlusion followed by $24 \mathrm{~h}$ reperfusion. For studies in (a-c), tissue samples were obtained from left ischemic hemispheres, and western blots in (c) were normalized with optic densities measured in $\beta$-actin blots (representative western blots are also shown). For studies in (d), animals had intrastriatally been pretreated with the solvent DMSO (control) or with the proteasome inhibitor BSc2118 $12 \mathrm{~h}$ before MCA occlusion. *Significantly different from WT mice (a-c) or from corresponding control mice (d), $P<0.05$. "Significantly different from $\mathrm{PrP}-/$ - or $\mathrm{PrP}+/+$ mice, $P<0.05$

PrP $+/+$ mice (Figures $6 b$ and $d$ ), which already showed very modest brain injury and motor coordination deficits under control conditions without NPC grafting. These data confirm that $\operatorname{PrP}^{\mathrm{C}}$ enables NPC migration and pathfinding in the ischemic brain.

\section{Discussion}

Using PrP ${ }^{c}$ wild type (WT), $\operatorname{PrP}^{c}$ knockout (PrP - / - ) and PrP ${ }^{c}$ overexpressing $(\mathrm{PrP}+/+)$ mice exposed to focal cerebral ischemia, we herein show that $\mathrm{PrP}^{\mathrm{c}}$ induces long-term neuroprotection that persists in the post-acute stroke phase, promoting neurological recovery via mechanisms involving enhanced neurogenesis and angiogenesis. Reduced proteasome activity was noted in the brains of ischemic $\mathrm{PrP}+/+$ mice, which went along with increased HIF-1a and PACAP-38 abundance, which are known to control NPC migration and trafficking. On the other hand, proteasome activity was increased in ischemic PrP-/- mice. Pharmacological proteasome inhibition reversed the exacerbation of ischemic brain injury induced by PrP $-/$, suggesting that proteasomal deactivation mediates the restorative effects of $\operatorname{PrP}^{c}$. $\operatorname{PrP}^{c}$ overexpression facilitated the intracerebral homing of systemically administered NPC, which was particularly impeded by $\operatorname{PrP}-/-$.

Previous studies analyzed the effect of $\operatorname{PrP}^{C}$ deficiency and overexpression after focal cerebral ischemia, reporting that $\mathrm{PrP}^{\mathrm{C}}$ deficiency aggravates, whereas $\mathrm{PrP}^{\mathrm{C}}$ overexpression reduces ischemic brain injury. ${ }^{20-24}$ Aggravation of ischemic injury by $\operatorname{PrP}^{\mathrm{C}}$ deficiency was found to involve Akt dephosphorylation, ERK-1/2 phosphorylation and caspase-3 activation. ${ }^{21,24}$ The precise mechanisms triggering these injurious events were unknown. By demonstrating that $\operatorname{PrP}^{\mathrm{c}}$ deactivates proteasome activity in ischemic brain tissue and 


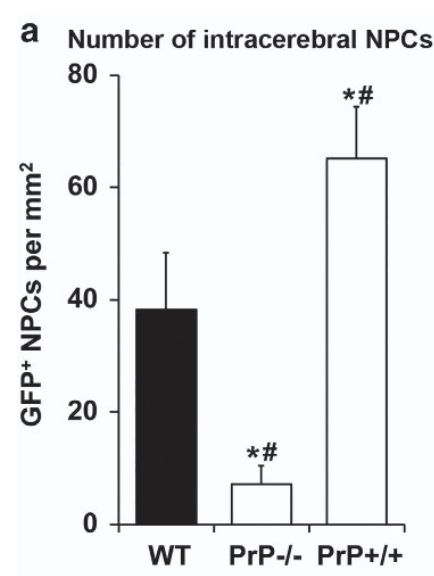

C

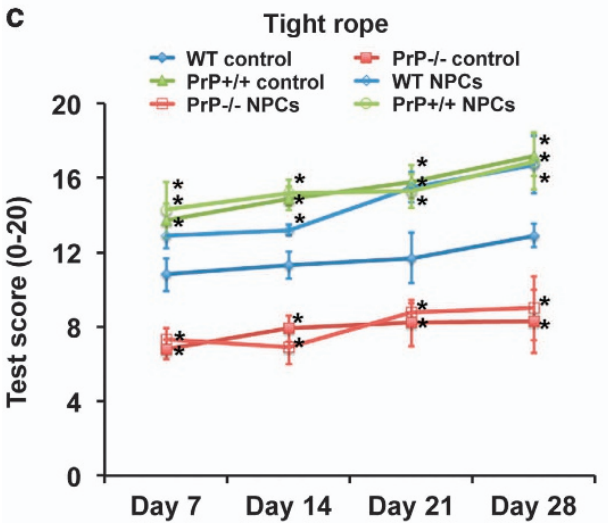

b
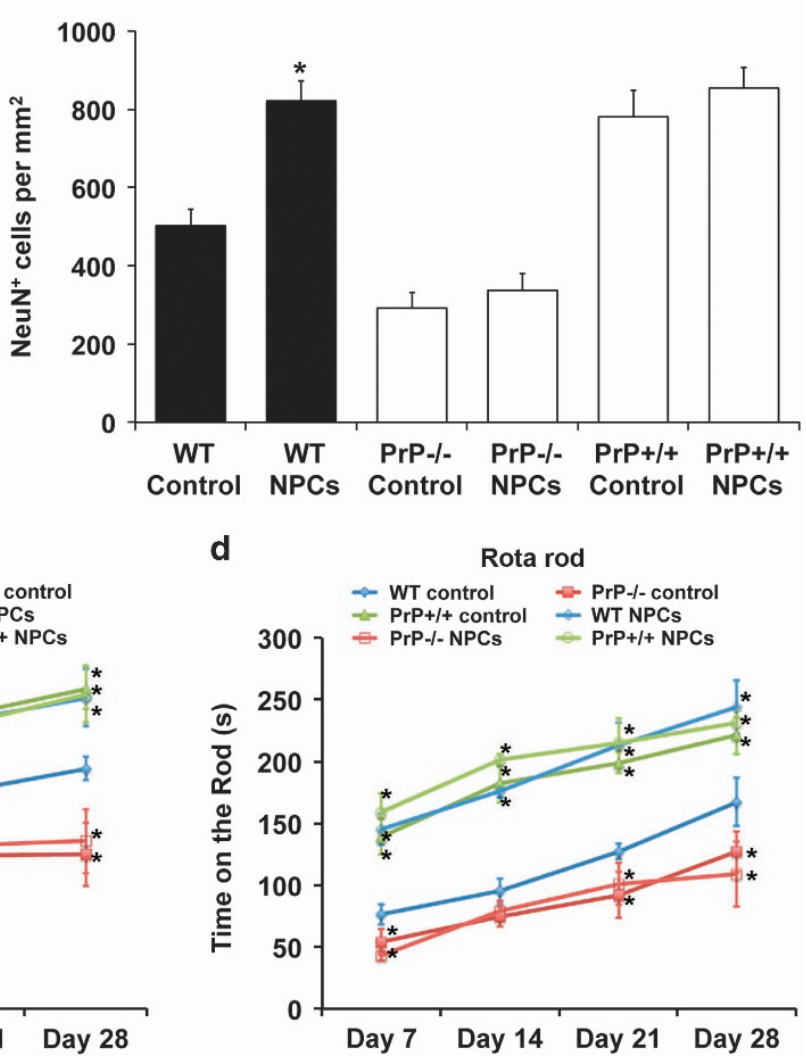

Figure $6 \mathrm{PrP}^{\mathrm{C}}$ enables peri-infarct homing of systemically delivered NPCs. (a) Density of GFP ${ }^{+}$NPCs in the ischemic striatum, (b) neuronal density in the ischemic striatum revealed by NeuN immunohistochemistry and (c and $\mathbf{d}$ ) motor coordination deficits evaluated by tight rope and rota rod tests of WT, PrP $-/-$ and PrP $+/+$ mice exposed to 45 min MCA occlusion followed by 28 days reperfusion. In (c and d), mice received intravenous transplantation of normal saline (control) or adult GFP ${ }^{+} \mathrm{NPCs}\left(10^{6}\right.$ cells in $300 \mu$ l normal saline) $6 \mathrm{~h}$ after reperfusion. *Significantly different from WT mice not receiving NPC treatment, $P<0.05$. "Significantly different from corresponding PrP $-/-$ or $\operatorname{PrP}+/+$ mice, $P<0.05$

that pharmacological proteasome inhibition reversed the effects of $\mathrm{PrP}-/$ - on infarct volume, we now provide such mechanism. ERK-1/2 has previously been found to be activated under conditions of proteasome activation. ${ }^{26-28}$ Proteasomal activation was found to augment ischemic brain injury via increased oxidative stress and HIF-1a degradation. $^{29}$

By comparison of WT, PrP $-/$ - and PrP $+/+$ mice, we for the first time show that $\mathrm{PrP}^{\mathrm{C}}$ promotes post-ischemic neurogenesis and angiogenesis. Neurogenesis and angiogenesis are closely linked in the ischemic brain, newly formed vessels providing guidelines for NPCs on their way to the stroke lesion. ${ }^{6}$ Newly formed blood vessels and NPCs mutually stimulate each other via release of trophic factors and guidance molecules. ${ }^{6,8,35}$ Neurogenesis and angiogenesis were increased both in ischemic $\mathrm{PrP}+/+$ and in $\mathrm{PrP}-/$ - mice. In PrP - / - mice, the increased neurogenesis and angiogenesis were attributed to the exacerbation of brain injury, as revealed in studies in which $\mathrm{PrP}-1$ - mice were exposed to a shorter ischemic episode, where cell proliferation and differentiation no more differed between WT and PrP $-/$ - mice. That increased post-stroke neurogenesis in $\mathrm{PrP}-/-$ mice does not go along with increased neurological recovery in these animals might appear to be contradictory only at first glance. As a matter of fact, the phenomenon of post-stroke neurogenesis is still under debate as stated afore. Even if newborn cells might positively modulate the post-ischemic milieu via indirect paracrine actions, ${ }^{33}$ this hypothetic beneficial effect might be outweighed by other pro-injurious cascades as, for instance, has been shown in the absence of ephrinB3. ${ }^{36}$ The brain accumulation of systemically delivered NPCs was markedly reduced by $\operatorname{PrP}-/-$, indicating that $\mathrm{PrP}^{\mathrm{C}}$ deficiency impedes NPC homing and survival.

By providing evidence that HIF-1a and its downstream signal PACAP-38 accumulates in ischemic brain tissue under conditions of $\mathrm{PrP}^{\mathrm{C}}$-induced proteasome deactivation, while $\mathrm{HIF}-1 \mathrm{a}$ is degraded as a consequence of $\mathrm{PrP}^{\mathrm{c}}$ deficiencyinduced proteasome overactivation, we identified a possible mechanism for the $\mathrm{PrP}^{\mathrm{C}}$-induced neurogenesis and angiogenesis. Pharmacological proteasome inhibition has previously been described to enhance post-ischemic neurological recovery, neurogenesis and angiogenesis via mechanisms involving HIF-1 $a$ accumulation. ${ }^{29} \mathrm{HIF}-1 a$ controls NPC migration and trafficking via PACAP- $38,{ }^{30-32}$ which is de novo expressed in the ischemic brain ${ }^{37}$ and itself promotes post-ischemic neurological recovery and neuronal survival. ${ }^{38}$ These observations are in line with Lee et al. who demonstrated increased post-ischemic levels of stress-inducible 
protein-1 (STI-1), which is a ligand of $\mathrm{PrP}^{\mathrm{c}}$, via binding of $\mathrm{HIF}-1 a$ to the STI-1 promoter, thus yielding enhanced homing of bone marrow-derived cells and neurological recovery. ${ }^{39}$ However, one has to keep in mind that despite the proteasome (and HIF-1a) being critically involved in the present work, the proteasomal activity certainly affects a plethora of cell cascades that are not exclusively analyzed herein.

By demonstrating that $\mathrm{PrP}^{\mathrm{c}}$ overexpression markedly enhances the intracerebral homing of systemically delivered adult NPCs, we finally confirmed that $\mathrm{PrP}^{\mathrm{c}}$ promotes NPC migration and trafficking. We have previously used the same protocol for the delivery of adult NPCs, demonstrating that adult NPCs promote neurological recovery after focal cerebral ischemia. ${ }^{33,34}$ In line with these earlier studies, NPC transplantation reduced neuronal injury and neurological deficits in ischemic WT mice, but failed to show any benefits in PrP - / or PrP +/+ mice. While the lack of effects in PrP - / - mice may be a consequence of low intracerebral numbers of grafted NPCs, the lack of effects in $\mathrm{PrP}+/+$ mice might rather represent a ceiling effect in animals exhibiting very subtle injury already under control conditions. Based on the presented data here, the $\mathrm{PrP}^{\mathrm{c}}$-proteasome-HIF-1a link might represent a promising target for restorative stroke therapies.

\section{Materials and Methods}

Experimental design. Experiments following the ARRIVE criteria were conducted in compliance with institutional guidelines and approved by local government authorities. All mice were strictly randomized, experimenters being blinded to experimental conditions. Male WT, PrP $-/$ - and $\mathrm{PrP}+/+$ mice $(24-27 \mathrm{~g})^{23,24,40}$ were kept under controlled circadian rhythm with free access to food and water. Mice were exposed to transient focal cerebral ischemia followed by $24 \mathrm{~h}$ or 28 days reperfusion. Survival rates were $100 \%$ for $24 \mathrm{~h}$ reperfusion and ranged from 81.3 to $100.0 \%$ for 28 days reperfusion (see Supplementary Table S1). For assessment of post-ischemic neurogenesis and angiogenesis on day 28, mice received daily single intraperitoneal (i.p.) injections of bromodeoxyuridine (BrdU; Sigma-Aldrich, Taufkirchen, Germany; $50 \mathrm{mg} / \mathrm{kg}$ ) on days 8-18 (see Supplementary Figure $\mathrm{S} 1$ for details of experimental protocol).

Induction of transient focal cerebral ischemia. Mice were exposed to transient focal cerebral ischemia using the intraluminal occlusion model as previously described by our group. ${ }^{29}$ Animals were deeply anesthetized with isoflurane $(1-1.5 \%)$ in $30 \% \mathrm{O}_{2}$ (remainder $\mathrm{N}_{2} \mathrm{O}$ ). After a neck midline incision, the left common carotid artery (CCA) was prepared and a silicon-coated monofilament (Doccol, Sharon, MA, USA) was inserted into the left CCA. The filament was gently moved forward until the offspring of the MCA. Thereafter, the filament was kept in situ for $45 \mathrm{~min}$ (for $30 \mathrm{~min}$ or $75 \mathrm{~min}$ in some experiments) under constant laser Doppler flowmetry, using a flexible probe attached to the skull overlying the left MCA territory. After filament removal, cerebral blood flow was monitored for additional $15 \mathrm{~min}$ in order to ensure adequate reperfusion. Rectal temperature was kept constantly at $36.5-37.0^{\circ} \mathrm{C}$ using a rectal probe attached to a feedback heating system.

Preparation of NPCs and cell transplantation. Adult SVZ-derived NPCs were generated as previously described. ${ }^{33}$ Preparations were done using male green fluorescence protein (GFP) transgenic mice (C57BL/6-Tg ACTB-enhanced green fluorescence protein, 10sb/J; JAX Laboratory, Bar Harbor, ME, USA, 6-8 weeks old), which carry the GFP gene under an actin promoter. For all experiments, GFP ${ }^{+}$NPCs from passages 3 to 8 were used. NPCs $\left(10^{6}\right.$ cells dissolved in $300 \mu \mathrm{l}$ normal saline) were grafted $6 \mathrm{~h}$ after stroke by intravenous infusion over $10 \mathrm{~min}$. Control animals received normal saline infusions. Animals were killed at $24 \mathrm{~h}$ or 28 days post-stroke.

Stereotactic injection of BSc2118. BSc2118 $(30 \mathrm{mg} / \mathrm{kg}$ dissolved in $5 \mu \mathrm{l}$ of $100 \%$ dimethyl sulfoxide (DMSO); synthesized and kindly provided by Drs Petra Henklein and Ulrike Kuckelkorn, Institute for Biochemistry, Charité, Berlin, Germany) was injected into the left-sided striatum using a stereotactic frame (injection coordinates $0.4 \mathrm{~mm}$ rostral, $3.5 \mathrm{~mm}$ ventral and $1.8 \mathrm{~mm}$ lateral from bregma) $12 \mathrm{~h}$ before stroke in animals anesthetized with ketamine $(10 \mathrm{mg} / \mathrm{kg})$ and xylazine $(25 \mathrm{mg} / \mathrm{kg})$. Control animals received $100 \%$ DMSO injections. Animals were killed at $24 \mathrm{~h}$ or 28 days post-stroke.

Assessment of post-stroke functional neurological recovery. Behavioral tests were performed using animals surviving for 28 days. Animals were trained for the behavioral tests 1-2 days before stroke induction. The tests included the rota rod, tight rope, corner turn and balance beam test as previously described ${ }^{41}$ In the rota rod test, the time until the animal dropped an accelerating rotating rod was recorded (maximal testing time $300 \mathrm{~s}$ ), whereas in the tight rope test the animal's ability to cross a tight rope was evaluated using a validated score from 0 ( $\min )$ to 20 (max). In the corner turn test, the animal was placed in an apparatus consisting of two vertical boards with an angle of $30^{\circ}$. When placed into the corner, a healthy animal randomly leaves the corner to either side, resulting in a laterality index of ' $0.5^{\prime}$. On the contrary, an ischemic mouse preferentially leaves the corner to the non-impaired body side (i.e. the left side), resulting in a laterality index of up to ' 1 ' (indicating most severe neurological impairment). The balance beam test consists of a long beam with constantly reduced width, which was elevated from the ground. Animals had to reach the platform at the end of the beam, and the time until they reached the platform was measured (maximum testing time $60 \mathrm{~s}$ ). All tests were performed twice on occasion of each time point, and means were calculated for both tests.

Histological and histochemical analysis. Brain injury at $24 \mathrm{~h}$ after stroke was analyzed using 2\% 2,3,5-triphenyltetrazolium chloride staining ( $n=6$ animals per condition). For this purpose, 2-mm-thick brain slices were obtained, which were evaluated by computer-based infarct volumetry using ImageJ software. Brain injury, cell proliferation, neurogenesis and angiogenesis on day 28 were assessed by immunohistochemistry in 20- $\mu$ m-thick cryostat sections $(n=12-15$ animals per condition). Three sections per animal were used which were incubated with the following primary antibodies: monoclonal mouse anti-BrdU (1:400; Roche, Basel, Switzerland), monoclonal rat anti-BrdU (1:400; Abcam, Cambridge, UK), polyclonal goat anti-doublecortin (1:50; Santa Cruz Biotechnology, Heidelberg, Germany), monoclonal mouse anti-NeuN (1:1000; Millipore, Darmstadt, Germany), monoclonal rat CD31 (1:200, BD Biosciences, Heidelberg, Germany) and polyclonal rabbit antiGFP (1:2500; Abcam, UK). Secondary antibodies were as follows: goat anti-mouse Cy-3 (1:400; Dianova, Germany), goat anti-rat Alexa 594 (1:400; Dianova), donkey anti-goat Alexa 488 (1:250; Invitrogen, Carlsbad, CA, USA), goat anti-mouse Alexa 488 (1:100; Jackson ImmunoResearch, Newmarket, UK) and goat anti-rat Alexa 488 (1:250; Invitrogen). Cell densities were evaluated under a fluorescence microscope in a total of four regions of interest in the ischemic striatum as previously described. ${ }^{41}$

Measurement of thiobarbituric acid reactive substances. During lipid peroxidation thiobarbituric acid reactive substances (TBARS) like malondialdehyde are formed, which react with thiobarbituric acid, giving rise to a chromogenic compound. ${ }^{33}$ Left ischemic hemispheres collected at $24 \mathrm{~h}$ post-stroke $(n=4$ animals per condition) were homogenized in cold lysis buffer ( $50 \mathrm{mmol} / \mathrm{T}$ Tris, $\mathrm{pH} 8.0$, $150 \mathrm{mmol} / \mathrm{l} \mathrm{NaCl}, 1 \%$ Triton X-100, protease inhibitors). In the homogenates, TBARS formation was photometrically measured at $\lambda=532 \mathrm{~nm}$, as described. ${ }^{33}$

Determination of proteasome activity. The chymotrypsine-like activity of the proteasome was measured in left ischemic hemispheres at $24 \mathrm{~h}$ after stroke ( $n=4$ animals per condition). ${ }^{29}$ Tissue samples were homogenized in cold lysis buffer containing $100 \mathrm{mM}$ Tris- $\mathrm{HCl}, 145 \mathrm{mM} \mathrm{NaCl}, 10 \mathrm{mM}$ ethylenediaminetetraacetic acid and $0.5 \%$ Triton $\mathrm{X}-100$ at pH 7.5. Samples were incubated with reaction buffer (50 mM Tris, $20 \mathrm{mM} \mathrm{KCl,} 2 \mathrm{mM}$ dithiothreitol, $1 \mathrm{mM}$ leupeptin (Sigma-Aldrich) and $1 \mathrm{mM}$ phenylmethylsulfonyl fluoride (Merck, Darmstadt, Germany). As a substrate, Suc-LLVY-AMC (Sigma-Aldrich) was added in a final concentration of $50 \mu \mathrm{M}$. Using a fluorescence microtiter plate reader, fluorescence was measured with $\lambda_{\text {exc. }} 355 \mathrm{~nm}$ and $\lambda_{\text {em. }} 460 \mathrm{~nm}$. Protease activities were presented as arbitrary units per min per $\mathrm{mg}$ of protein. Protein concentration was determined using the Bradford assay.

Western blots. Tissue samples obtained from left ischemic hemispheres at $24 \mathrm{~h}$ after stroke ( $n=4$ animals per condition) were homogenized in $50 \mathrm{mmol} / \mathrm{l}$ Tris, $\mathrm{pH} 8.0,150 \mathrm{mmol} / \mathrm{I} \mathrm{NaCl}, 1 \%$ Triton X-100 and protease inhibitors, followed by sodium dodecyl sulfate-polyacrylamide gel electrophoresis using equal amounts of protein. The following primary antibodies were used: polyclonal rabbit anti-HIF-1 $\alpha$ 
(Abcam) and polyclonal rabbit PACAP-38 (Calbiochem, Darmstadt, USA). Protein loading was controlled using $\beta$-actin blots. Membranes were scanned for densitometric analysis of protein abundance.

Statistics. Data are given as means \pm standard deviation (S.D.). For comparisons between two groups, Student's $t$-tests were used. For comparisons of multiple groups, one-way analysis of variance followed by the Tukey's post hoc tests were performed. $P$-values $<0.05$ were considered statistically significant.

\section{Conflict of Interest}

The authors declare no conflict of interest.

Acknowledgements. We thank Drs Petra Henklein and Ulrike Kuckelkorn (both Charité, Berlin, Germany) for synthesizing and providing the proteasome inhibitor BSc2118. The study was supported by TUBITAK (\#2221 to TRD) and by the German Research Council (\#HE3173/2-2 and \#HE3173/3-1 to DMH).

1. Stolp HB, Molnar Z. Neurogenic niches in the brain: help and hindrance of the barrier systems. Front Neurosci 2015; 9: 20.

2. Urban N, Guillemot F. Neurogenesis in the embryonic and adult brain: same regulators, different roles. Front Cell Neurosci 2014; 8: 396.

3. Fuchs E, Flugge G. Adult neuroplasticity: more than 40 years of research. Neural Plast 2014 2014: 541870.

4. Braun SM, Jessberger S. Adult neurogenesis: mechanisms and functional significance. Development 2014; 141: 1983-1986.

5. Arvidsson A, Collin T, Kirik D, Kokaia Z, Lindvall O. Neuronal replacement from endogenous precursors in the adult brain after stroke. Nat Med 2002; 8: 963-970.

6. Hermann DM, Chopp M. Promoting brain remodelling and plasticity for stroke recovery: therapeutic promise and potential pitfalls of clinical translation. Lancet Neurol 2012; 11 : 369-380.

7. Tobin MK, Bonds JA, Minshall RD, Pelligrino DA, Testai FD, Lazarov O. Neurogenesis and inflammation after ischemic stroke: what is known and where we go from here. $J$ Cereb Blood Flow Metab 2014; 34: 1573-1584.

8. Haas S, Weidner N, Winkler J. Adult stem cell therapy in stroke. Curr Opin Neurol 2005; 18: 59-64.

9. Doeppner TR, Dietz GP, El Aanbouri M, Gerber J, Witte OW, Bahr M et al. TAT-Bcl-x(L) improves survival of neuronal precursor cells in the lesioned striatum after focal cerebral ischemia. Neurobiol Dis 2009; 34: 87-94.

10. Yu TS, Washington PM, Kernie SG. Injury-induced neurogenesis: mechanisms and relevance. Neuroscientist 2014, Dec 17. pii: 1073858414563616. [Epub ahead of print]

11. Colby DW, Prusiner SB. Prions. Cold Spring Harbor Perspect Biol 2011; 3: a006833.

12. Gill AC, Agarwal S, Pinheiro TJ, Graham JF. Structural requirements for efficient prion protein conversion: cofactors may promote a conversion-competent structure for $\operatorname{Pr} P(C)$. Prion 2010; 4: 235-242.

13. Caiati MD, Safiulina VF, Fattorini G, Sivakumaran S, Legname G, Cherubini E. PrPC controls via protein kinase $A$ the direction of synaptic plasticity in the immature hippocampus. J Neurosci 2013; 33: 2973-2983.

14. Peralta OA, Huckle WR, Eyestone WH. Developmental expression of the cellular prion protein $(\operatorname{PrP}(C))$ in bovine embryos. Mol Reprod Dev 2012; 79: 488-498.

15. Bribian A, Fontana X, Llorens F, Gavin R, Reina M, Garcia-Verdugo JM et al. Role of the cellular prion protein in oligodendrocyte precursor cell proliferation and differentiation in the developing and adult mouse CNS. PloS One 2012; 7: e33872.

16. Peralta OA, Huckle WR, Eyestone WH. Expression and knockdown of cellular prion protein (PrPC) in differentiating mouse embryonic stem cells. Differentiation 2011; 81: 68-77.

17. Steele AD, Emsley JG, Ozdinler PH, Lindquist S, Macklis JD. Prion protein (PrPc) positively regulates neural precursor proliferation during developmental and adult mammalian neurogenesis. Proc Natl Acad Sci USA 2006; 103: 3416-3421.

18. Turu $M$, Slevin $M$, Ethirajan $P$, Luque A, Elasbali A, Font $A$ et al. The normal cellular prion protein and its possible role in angiogenesis. Front Biosci 2008; 13: 6491-6500.

19. Pham N, Dhar A, Khalaj S, Desai K, Taghibiglou C. Down regulation of brain cellular prion protein in an animal model of insulin resistance: possible implication in increased prevalence of stroke in pre-diabetics/diabetics. Biochem Biophys Res Commun 2014; 448: 151-156.

20. Shyu WC, Lin SZ, Chiang MF, Ding DC, Li KW, Chen SF et al. Overexpression of PrPC by adenovirus-mediated gene targeting reduces ischemic injury in a stroke rat model. J Neurosci 2005; 25: 8967-8977.

21. Spudich A, Frigg R, Kilic E, Kilic U, Oesch B, Raeber A et al. Aggravation of ischemic brain injury by prion protein deficiency: role of ERK-1/-2 and STAT-1. Neurobiol Dis 2005; 20 442-449.
22. Weise J, Crome O, Sandau R, Schulz-Schaeffer W, Bahr M, Zerr I. Upregulation of cellular prion protein $(\mathrm{PrPc})$ after focal cerebral ischemia and influence of lesion severity. Neurosci Lett 2004; 372: 146-150.

23. Weise J, Doeppner TR, Muller T, Wrede A, Schulz-Schaeffer W, Zerr I et al. Overexpression of cellular prion protein alters postischemic Erk $1 / 2$ phosphorylation but not Akt phosphorylation and protects against focal cerebral ischemia. Restor Neurol Neurosci 2008; 26: 57-64

24. Weise J, Sandau R, Schwarting S, Crome O, Wrede A, Schulz-Schaeffer W et al. Deletion of cellular prion protein results in reduced Akt activation, enhanced postischemic caspase-3 activation, and exacerbation of ischemic brain injury. Stroke 2006; 37: 1296-1300.

25. Zechariah A, EIAli A, Doeppner TR, Jin F, Hasan MR, Helfrich I et al. Vascular endothelial growth factor promotes pericyte coverage of brain capillaries, improves cerebral blood flow during subsequent focal cerebral ischemia, and preserves the metabolic penumbra. Stroke 2013; 44: 1690-1697.

26. Cirit M, Grant KG, Haugh JM. Systemic perturbation of the ERK signaling pathway by the proteasome inhibitor, MG132. PloS One 2012; 7: e50975.

27. Rastogi N, Mishra DP. Therapeutic targeting of cancer cell cycle using proteasome inhibitors. Cell Div 2012; 7: 26.

28. Tanimoto $\mathrm{Y}$, Kizaki H. Proteasome inhibitors block Ras/ERK signaling pathway resulting in the downregulation of Fas ligand expression during activation-induced cell death in T cells. J Biochem 2002; 131: 319-326.

29. Doeppner TR, Mlynarczuk-Bialy I, Kuckelkorn U, Kaltwasser B, Herz J, Hasan MR et al. The novel proteasome inhibitor BSc2118 protects against cerebral ischaemia through HIF1A accumulation and enhanced angioneurogenesis. Brain 2012; 135(Pt 11): 3282-3297.

30. Matsuno R, Ohtaki H, Nakamachi T, Watanabe J, Yofu S, Hayashi D et al. Distribution and localization of pituitary adenylate cyclase-activating polypeptide-specific receptor (PAC1R) in the rostral migratory stream of the infant mouse brain. Regul Pept 2008; 145: 80-87.

31. Nishimoto M, Furuta A, Aoki S, Kudo Y, Miyakawa H, Wada K. PACAP/PAC1 autocrine system promotes proliferation and astrogenesis in neural progenitor cells. Glia 2007; 55 : 317-327.

32. Zhu Y, Cao L, Su Z, Mu L, Yuan Y, Gao L et al. Olfactory ensheathing cells: attractant of neural progenitor migration to olfactory bulb. Glia 2010; 58: 716-729.

33. Doeppner TR, Ewert TA, Tonges L, Herz J, Zechariah A, Elali A et al. Transduction of neural precursor cells with TAT-heat shock protein 70 chaperone: therapeutic potential against ischemic stroke after intrastriatal and systemic transplantation. Stem Cells 2012; 30: 1297-1310.

34. Bacigaluppi M, Pluchino S, Peruzzotti Jametti L, Kilic E, Kilic U, Salani G et al. Delayed postischaemic neuroprotection following systemic neural stem cell transplantation involves multiple mechanisms. Brain 2009; 132(Pt 8): 2239-2251.

35. Parent JM. Injury-induced neurogenesis in the adult mammalian brain. Neuroscientist 2003; 9: $261-272$.

36. Doeppner TR, Bretschneider E, Doehring M, Segura I, Senturk A, Acker-Palmer A et al. Enhancement of endogenous neurogenesis in ephrin-B3 deficient mice after transient focal cerebral ischemia. Acta Neuropathol 2011; 122: 429-442.

37. Stumm R, Kolodziej A, Prinz V, Endres M, Wu DF, Hollt V. Pituitary adenylate cyclaseactivating polypeptide is up-regulated in cortical pyramidal cells after focal ischemia and protects neurons from mild hypoxic/ischemic damage. J Neurochem 2007; 103: 1666-1681.

38. Brifault C, Gras M, Liot D, May V, Vaudry D, Wurtz $O$. Delayed pituitary adenylate cyclaseactivating polypeptide delivery after brain stroke improves functional recovery by inducing $\mathrm{m} 2$ microglia/macrophage polarization. Stroke 2015; 46: 520-528.

39. Lee S-D, Lai TW, Lin S-Z, Lin C-H, Hsu Y-H, Li C-Y et al. Role of stress-inducible protein-1 in recruitment of bone marrow derived cells into the ischemic brains. EMBO Mol Med 2013; 5: 1227-1246.

40. Williams SK, Fairless R, Weise J, Kalinke U, Schulz-Schaeffer W, Diem R. Neuroprotective effects of the cellular prion protein in autoimmune optic neuritis. Am J Pathol 2011; 178: 2823-2831.

41. Doeppner TR, Kaltwasser B, Bahr M, Hermann DM. Effects of neural progenitor cells on post-stroke neurological impairment-a detailed and comprehensive analysis of behavioral tests. Front Cell Neurosci 2014; 8: 338.

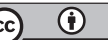

Cell Death and Disease is an open-access journal published by Nature Publishing Group. This work is licensed under a Creative Commons Attribution 4.0 International License. The images or other third party material in this article are included in the article's Creative Commons license, unless indicated otherwise in the credit line; if the material is not included under the Creative Commons license, users will need to obtain permission from the license holder to reproduce the material. To view a copy of this license, visit http://creativecommons.org/licenses/by/4.0/ 